\title{
Environment Impact Assessment and Environment Management Studies for an Upcoming Multiplex - A Case Study
}

\author{
Manmeet Kaur ${ }^{1}$, Dr. Shakti Arora ${ }^{2}$ \\ ${ }^{1}$ M.E student, 2nd Year, Department of Environmental Engineering, PEC University of technology, Chandigarh \\ ${ }^{2}$ Associate Professor, Department of Civil Engineering, PEC University of technology, Chandigarh
}

\begin{abstract}
Environmental Impact Assessment can be defined as the systematic process of identifying and evaluating the future consequences of a current or proposed action relative to the physical, chemical, biological, cultural and socioeconomic components of the environment. Any development project plan to improve the quality of life has some built-in positive and negative impacts. The development project should, thus, be planned in such a manner that it has maximum positive impacts and minimum negative impacts on the environment. The purpose of incorporating EIA approaches has been described as subjecting a proposed action to an examination of what the possible environmental impacts of that action would be and to find ways to mitigate any negative long term impacts.

This paper highlights the importance of EIA in the sustainable development of a Construction project with a case study of an upcoming Multiplex in BalloMajra near Mohali (Punjab). The parameters covered in present work are Biological, Air, Water, Noise, Soil and Socio-Economic. A study period from January 2012 to April 2012 was selected for collection of Base Line Environmental Data. The impact of various environmental parameters, due to the proposed project has been predicted and depending on them mitigation measures have been suggested.
\end{abstract}

The 'Leopold Impact Matrix' has been used to evaluate the impacts of various parameters. With the help of 'Leopold Impact Matrix' the impact of the environmental changes, due to the project, with and without the mitigation measures has been evaluated. Finally, an Environment Impact Statement has been prepared.

Keywords: Environment Impact Assessment, environmental pollution, Construction activities, Environmental impact of construction.

\section{Introduction}

Environmental protection is an important issue throughout the world (Tse and Raymond, 2001). Compared with other industries, construction is a main source of environmental pollution (Shen et al., 2005). Building construction and operations have a massive direct and indirect effect on the environment (Levin, 1997). Pollution sources from the construction process include harmful gases, noise, dust, solid and liquid waste (Chen et al., 2000).

Enhancing the identification of the major environmental impacts of construction processes will help to improve the effectiveness of environmental management systems. Furthermore, prediction of the correlated environmental impacts of construction before the construction stage, will lead to improvements in the environmental performance of construction projects and sites. The determination of major environmental impacts will assist to consider a range of on-site measures in order to mitigate those (Gangolells et al., 2011).

Any large scale project is expected to cause environmental impacts near the project site during its construction and operational phase. The type and intensity of the impacts on the environment depends not only on the nature and size of the project but also on the geographical location. The net impact from individual project can be quantified through EIA studies for various components like air, water, land, noise, socio-economic environment prior to implementation of the project.

With rapid growth of shopping malls, multiplexes etc there is rise in living standards but this has also led to degradation of environment too. During the construction and operational phases of these malls, there is pollution of air, water, land, noise which has direct impacts on our environment.

EIA is generally viewed as a framework for considering issues regarding location, design of projects and the environment in parallel, and by that producing better designed projects having in mind both the environment and the economy. In the past decade, with increasing force during the last couple of years, new ideas about the purpose of the EIA process have sprung to life focusing on the potential benefits of the EIA process to increase acceptance of proposed projects. 


\section{Methodology:}

The present study has been selected for an upcoming hotel, Multiplex, Offices and Shopping Mall Project. M/s Hamir Real Estate (P) Ltd is setting up a hotel, multiplex, and offices and shopping Mall project in the name of "Virsa Mall" at Ballo Majra, S.A.S Nagar at Mohali. The project has a spread of 87452.60 square metre (21.61 Acres) which falls under Mix land use as per GMADA Master Plan. The site is located on the national highway-2(NH 21, connecting Chandigarh to Ropar). Chandigarh and Mohali are located at an approximate distance of $17 \mathrm{~km}$ and $6 \mathrm{~km}$ respectively from the proposed site.

The project is a designated project under Schedule and falls under category B1 of the Environmental Impact Assessment Notification. In this, study of baseline environmental status has been carried out in terms of different environmental attributes. Then, the extensive EIA for the project has been prepared which includes impact predictions on identified parameters and mitigation measures have been suggested. Further, the evaluation of total impacts has been done using Leopold Matrix method, which helps in incorporating proper mitigation measures wherever necessary for preventing significant effect on the environment.

\section{Baseline Environmental Data}

Air quality:

The environmental quality status with respect to ambient air quality status was established through intensive monitoring of ambient air quality within the impact zone i.e $10 \mathrm{~km}$ of the proposed project site. The location of AAQM stations was finalised. The parameters for AAQM study were S.P.M, SOx, NOx. The area is residential. Table below shows the four sites selected for air quality monitoring.

The location 1 that is the site of the mall is further divided into two sampling locations which are (a) near the gate and (b) near the multiplex. These sampling sites within the project area are given a location code as $\mathrm{L} 1 \mathrm{a}$ and L1b respectively.

\begin{tabular}{|l|l|l|l|}
\hline LOCATION & $\begin{array}{l}\text { LOCATION } \\
\text { CODE }\end{array}$ & NAME OF PLACE & DIRECTION \\
\hline \multirow{2}{*}{ Location 1 } & L1 & Ballo Majra(Site) & -- \\
\cline { 2 - 4 } & L1a & Near the gate & \\
\cline { 2 - 4 } & L1b & Near the multiplex & \\
\hline Location 2 & L2 & Sohana & SE \\
\hline Location 3 & L3 & Atawa & E \\
\hline Location 4 & L4 & Khanpur & W \\
\hline Location 5 & L5 & Togan & NE \\
\hline
\end{tabular}

The results of Air quality sampling for the different sites is given below:

\begin{tabular}{|c|c|c|c|c|c|c|c|c|c|c|}
\hline \multirow[t]{2}{*}{ S.No } & \multirow[t]{2}{*}{ Location } & \multicolumn{3}{|c|}{ SPM $(\mu \mathrm{g} / \mathrm{m} 3)$} & \multicolumn{3}{|c|}{ SOx $(\mu \mathrm{g} / \mathrm{m} 3)$} & \multicolumn{3}{|c|}{ NOx $(\mu \mathrm{g} / \mathrm{m} 3)$} \\
\hline & & Max. & Min. & Avg & Max. & Min. & Avg & Max. & Min. & Avg \\
\hline \multirow[t]{2}{*}{1.} & L1a & 245.65 & 196.34 & 220.99 & 6.84 & 4.13 & 5.48 & 18.80 & 16.01 & 17.40 \\
\hline & L1b & 284.12 & 210.10 & 247.11 & 8.31 & 5.65 & 6.98 & 17.91 & 15.61 & 16.67 \\
\hline 2. & L2 & 225.64 & 192.35 & 208.99 & 7.49 & 4.35 & 6.42 & 13.89 & 12.56 & 13.22 \\
\hline 3. & L3 & 224.47 & 188.84 & 206.65 & 8.17 & 4.32 & 6.24 & 18.04 & 14.21 & 16.12 \\
\hline 4. & L4 & 234.74 & 174.37 & 204.55 & 6.89 & 5.94 & 6.40 & 15.68 & 11.92 & 13.80 \\
\hline 5. & L5 & 219.76 & 178.58 & 199.17 & 6.90 & 5.78 & 6.34 & 14.15 & 10.38 & 12.26 \\
\hline
\end{tabular}

Inference:

SPM: The maximum value of SPM observed at all the monitoring locations was $284.12 \mu \mathrm{g} / \mathrm{m} 3$ which exceeds the NAAQ standards.

SO2: The monitoring was conducted at all the stations around the project site. The SO2 values are well within the permissible limits in all the locations.

NO2: The NOx values were found to be well within the permissible limits in all the locations.

\section{Water Environment:}

Ground water is the principle source of water for domestic, industrial and irrigation purposes. Ground water samples were extracted from bore wells and hand pumps and were analysed. The sampling was done at site also. Four ground water samples were collected from bore wells and hand pumps and one surface water sample was collected from canal located near Balongi village. 
The water quality monitoring locations are given below:

\begin{tabular}{|l|l|l|}
\hline S.NO & LOCATION & LOCATION CODE \\
\hline 1. & Bore well- Project site & GW1 \\
\hline 2. & Bore well- Sohana & GW2 \\
\hline 3. & Hand pump- Togan & GW3 \\
\hline 4. & Hand Pump- Khanpur & GW4 \\
\hline 5. & $\begin{array}{l}\text { Surface water (near } \\
\text { Balongi village) }\end{array}$ & SW1 \\
\hline
\end{tabular}

The results of the analysis and their comparison with Indian standards are reported in the table below:

\begin{tabular}{|c|c|c|c|c|c|c|c|}
\hline \multirow{2}{*}{$\begin{array}{l}\mathbf{S} . \\
\mathbf{N} \\
\mathbf{0}\end{array}$} & \multirow{2}{*}{$\begin{array}{c}\text { Test } \\
\text { Paramete } \\
\text { r }\end{array}$} & \multirow[t]{2}{*}{ Units } & \multicolumn{4}{|c|}{ Location } & \multirow{2}{*}{$\begin{array}{c}\text { IS-10500- } \\
1991\end{array}$} \\
\hline & & & GW1 & GW2 & GW3 & GW4 & \\
\hline 1. & Colour & $\begin{array}{l}\text { Hazen } \\
\text { unit }\end{array}$ & $<5$ & $<5$ & $<5$ & $<5$ & $<5$ \\
\hline 2. & Odour & - & $\begin{array}{l}\text { Unobjectio } \\
\text { nable }\end{array}$ & $\begin{array}{l}\text { Unobjec } \\
\text { tionable }\end{array}$ & $\begin{array}{l}\text { Unobjec } \\
\text { tionable }\end{array}$ & $\begin{array}{l}\text { Unobjec } \\
\text { tionable }\end{array}$ & \\
\hline 3. & Taste & - & Agreeable & $\begin{array}{l}\text { Agreeab } \\
\text { le }\end{array}$ & $\begin{array}{l}\text { Agreeab } \\
\text { le }\end{array}$ & $\begin{array}{l}\text { Agreeab } \\
\text { le }\end{array}$ & \\
\hline 4. & Turbidity & NTU & $<5$ & $<5$ & $<5$ & $<5$ & $<5$ \\
\hline 5. & $\mathrm{pH}$ & - & 7.12 & 7.0 & 7.3 & 7.0 & $6.5-8.5$ \\
\hline 6. & $\begin{array}{l}\text { Total } \\
\text { Hardness }\end{array}$ & $\begin{array}{l}\mathrm{mg} / \mathrm{l} \\
\mathrm{as} \\
\mathrm{CaCO} 3\end{array}$ & 190 & 240 & 248 & 240 & $<300$ \\
\hline 7. & Iron & $\mathrm{mg} / \mathrm{l}$ & 0.07 & 0.14 & 0.10 & 0.12 & $<0.3$ \\
\hline 8. & Chlorides & $\mathrm{mg} / \mathrm{l}$ & 21.5 & 22 & 22.1 & 24.03 & $<250$ \\
\hline
\end{tabular}

\section{Noise Environment:}

Noise levels were measured at the same locations as for Air Quality Monitoring. The locations for noise monitoring at the project site were selected as below (when DG set is $\mathrm{ON}$ ):

\begin{tabular}{|c|c|}
\hline LOCATION & LOCATION CODE \\
\hline In front of electric room & $\mathrm{N} 1$ \\
\hline Besides electric room & $\mathrm{N} 2$ \\
\hline Near batching plant & $\mathrm{N} 3$ \\
\hline Near basement area & $\mathrm{N} 4$ \\
\hline Near temporary office & N5 \\
\hline
\end{tabular}

The measured noise levels at different locations are as follows:

\begin{tabular}{|c|l|c|}
\hline \multicolumn{2}{|c|}{ LOCATION } & DAY TIME \\
\cline { 3 - 3 } \multicolumn{4}{|c|}{ L1 } & N1 & Leq(dB(A)) \\
\cline { 2 - 3 } & N2 & 75.2 \\
\cline { 2 - 3 } & N3 & 74.8 \\
\cline { 2 - 3 } & N4 & 74.9 \\
\cline { 2 - 3 } & N5 & 73.5 \\
\hline \multirow{2}{*}{ L2 } & 73.8 \\
\hline L3 & 53 \\
\hline \multicolumn{2}{|c|}{ L4 } & 53 \\
\hline
\end{tabular}

The results of daytime noise monitoring at all the locations other than the site are within the AAQS noise limits while at the project site noise level is beyond the permissible limits, when the DG sets are ON. 


\section{Land Environment:}

The soil in the area is classified into reddish chestnut soil and tropical arid brown soil. The soils are generally deficient in nitrogen and responds to nitrogen application. Soil samples have been collected from the depth of 1 feet from the project site.

The results of soil sample (project site) analysis are given below:

\begin{tabular}{|c|c|c|}
\hline S.No & Parameter & Results \\
\hline 1. & $\mathrm{pH}$ & 7.11 \\
\hline 2. & $\begin{array}{c}\text { Soil moisture } \\
\text { content }\end{array}$ & $30.12 \%$ \\
\hline 3. & Bulk Density & $1.10 \mathrm{~g} / \mathrm{cm} 3$ \\
\hline 4. & Nitrogen & $0.20 \mathrm{ppm}$ \\
\hline 5. & Sodium & $\begin{array}{c}0.13 \\
\mathrm{mg} / 100 \mathrm{~g}\end{array}$ \\
\hline 6. & Potassium & $\begin{array}{c}0.07 \\
\mathrm{mg} / 100 \mathrm{~g}\end{array}$ \\
\hline
\end{tabular}

\section{Biological Environment:}

Forests:

The recorded forest area in the Punjab state is 3,058 square kilometres which is $6.12 \%$ of the geographical area of the state. Reserved forests constitute $1.43 \%$, protected forests $36.87 \%$ and un-classed forests constitute $61.70 \%$.

Wildlife:

The project site has no protected areas located within the study site. Besides, the proposed project area is not located within an existing or any proposed ecologically sensitive zone known for providing habitat and movement corridor for any kind of animals. Hence the impact of the project on the wildlife is not expected. There is little evidence of small mammals, reptiles and birds on the site.

\section{Flora:}

The principal crops are wheat, paddy, potato, tomato, cauliflower, cabbage and all type of pulses.

The major species found in this area are

1. Achyranthus aspera

2. Argemone Mexicana

3. Aristida hystrix

4. Cassia tora

5. Chloris Montana

6. Cynodon dactylon

7. Mimos sp.

8. Parthenium sp.

9. Phragmites karlea

10. Saccharum munja

11. Saccharum spontaneum

12. Tribulus terrestris

13. Tridax procumbens

Source: forest department, Punjab

\section{Fauna:}

No wild mammalian species was directly in the study area. The different bird species found in the study area are:

\begin{tabular}{|l|l|l|}
\hline S.No & English Name & Scientific Name \\
\hline 1. & Pariah kite & Milvus migrans \\
\hline 2. & Red- wattled lapwing & Vanellus indicus \\
\hline 3. & Spotted dove & Streptopelia chinensis \\
\hline 4. & Large Indian parakeet & Psittaculla eupatoria \\
\hline 5. & White breasted king fisher & Haleyon smyrensis \\
\hline 6. & Indian roller & Coracias benhalensis \\
\hline 7. & Indian hoopoe & Upupa epops \\
\hline 8. & Common green bee eater & Merops orientalis \\
\hline 9. & Common myna & Acridotheres tristis \\
\hline 10. & Black Drongo & Dicrurus adsimilis \\
\hline 11. & Coucal & Centropus sinensis \\
\hline
\end{tabular}

Source: forest department, Punjab 
Environment Impact Assessment And Environment management Studies For An Upcoming Multiplex-A Case

\section{Socio-Economic Environment:}

Punjab is situated in the north western corner of the country. It is bounded on the north by the Indian state of Jammu \& Kashmir and east by Himachal Pradesh and the union territory of Chandigarh, on south by Haryana and Rajasthan and on west by Pakistan.

The rural population of Punjab has decreased from 66.08 to 62.51 from 2001 to 2011 . The city of Sahibzada Ajit Singh Nagar, popularly known as S.A.S Nagar was declared as $18^{\text {th }}$ district of Punjab on $14^{\text {th }}$ April, 2006. Its population in 2011 census was 986,147, out of which 442,112 is rural and 544,035 urban.

The study area for socioeconomic assessment was defined as an area within ten kilometre radius around the project site.

\section{Demographic Structure:}

A detailed breakup of population (urban and rural \& sex wise) compared with state average is given below

\begin{tabular}{|l|l|l|l|l|l|l|l|l|}
\hline \multicolumn{1}{|c|}{ AREA } & \multicolumn{3}{|c|}{ POPULATION } & \multicolumn{3}{c|}{ MALE FEMALE RATIO } \\
\hline & \multicolumn{2}{|c|}{2001} & \multicolumn{2}{c|}{2011} & \multicolumn{2}{c|}{2001} & \multicolumn{2}{c|}{2011} \\
\hline & Rural\% & Urban\% & Rural\% & Urban\% & Rural & Urban & Rural & Urban \\
\hline S.A.S Nagar & 61.67 & 38.33 & 44.83 & 55.17 & 832 & 858 & 868 & 887 \\
\hline Punjab State & 66.08 & 33.92 & 62.51 & 37.49 & 890 & 849 & 906 & 872 \\
\hline
\end{tabular}

\section{Literacy:}

The average literacy rate of Punjab is $76.7 \%$ and that for S.A.S Nagar is 84.9 . The summary for literacy rate is given below:

\begin{tabular}{|c|c|l|l|l|l|l|l|l|}
\hline AREA & \multicolumn{4}{|c|}{ LITERACY RATE(MALES) } & \multicolumn{3}{c|}{$\begin{array}{c}\text { LITERACY } \\
\text { RATE(FEMALES) }\end{array}$} \\
\hline & \multicolumn{2}{|c|}{2001} & \multicolumn{2}{|c|}{2011} & \multicolumn{2}{c|}{2001} & \multicolumn{2}{c|}{2011} \\
\hline & Rural & Urban & Rural & Urban & Rural & Urban & Rural & Urban \\
\hline S.A.S Nagar & 79.66 & 89.38 & 85.37 & 92.28 & 65.65 & 80.62 & 73.65 & 85.10 \\
\hline Punjab State & 71.05 & 83.05 & 77.92 & 87.28 & 57.72 & 74.49 & 66.47 & 79.62 \\
\hline
\end{tabular}

Source: Director of Census Operations, Punjab

\section{Identification Of Pollution Sources And Its Quantification}

1) Air emissions: From vehicular exhaust

Dust during construction

From D.G sets

\begin{tabular}{|c|c|}
\hline Pollutant & Emission Rate \\
\hline SPM & 0.30 \\
\hline SO2 & 0.70 \\
\hline NO2 & 5.50 \\
\hline
\end{tabular}

2) Noise emissions:

From various construction equipments

From air compressors

From D.G sets

From vehicles

The construction equipments and other sources will generate noise within the range of 70 to $120 \mathrm{~dB}(\mathrm{~A})$ within the vicinity of construction site.

3) Waste:

From construction activities

From labour camps

From Sewage treatment plant (STP)

From other sources

Solid waste generation taking into account 18221 persons @ $0.15 \mathrm{~kg} /$ day is $2733.15 \mathrm{kd} /$ day.

The waste generated during operational phase is categorised as biodegradable, recyclable, inert/ recyclable and hazardous. Out of the total waste generated $50 \%$ of it would be biodegradable, $20 \%$ of the waste would be recyclable, $30 \%$ would be inert and it is assumed that a small quantity $(0.3 \% \mathrm{~s})$ of it would be hazardous waste.

4) Waste water:
From construction activities

From sewage

From commercial activities

From other sources 
It has been assumed that $80 \%$ of the water supplied would be discharged as wastewater. Hence approximately $717 \mathrm{KLD}$ of waste water would be generated.

VI. Identification Of Impacts Of Other Aspects:

1) On Water: Abundant water would be available for this project and supply would be met through deep bore wells. Water demand during operation phase is 19, 94,418 litres/day. $717 \mathrm{~m} 3 /$ day of treated waste water would be generated from sewage treatment plant that would be used for flushing, horticulture and other activities.

2) On Air: There would be no significant impact on the air environment from the project development after the implementation of proposed control techniques. The impacts of climatic, seasonal factors would be more significant on overall air environment than construction activity.

3) On Noise: There would be no adverse impact on area from activities of construction project when proper shields and other control measures are adopted.

4) On soil: There would be no adverse impact since the treated waste water would be reused for the construction activities or for watering the plants.

5) On Socio- Economy: There will be noticeable indirect employment and significant direct employment, therefore economic distribution to the area and alternate income \& employment to population dependent on agriculture and land based occupations.

\section{Evaluation Of Impacts: Presentation In Matrix Form}

The impact prediction is represented in the form of a Matrix. A derivative of 'Leopold and Interaction form of matrices' has been used. Scoring of the impact ranges from -10 to 10. These scorings are represented below:

\begin{tabular}{|c|c|c|}
\hline Effect & Impact & Score \\
\hline No effect & No impact & 0 to 1 \\
\hline Short term & Slight impact & 2 \\
\hline $\begin{array}{c}\text { Occasionally } \\
\text { reversible }\end{array}$ & Appreciable & 4 \\
\hline Long term & Considerable & 6 \\
\hline Permanent & Permanent & 8 \\
\hline Drastic & Immediate & 10 \\
\hline
\end{tabular}

The activity impact matrix has been evaluated and prepared. The significance of weighted score evaluated is as:

- $\quad$ Upto 2500

- $2500-5000$

- $5000-7500$

- $7500-10000$

- $>10000$ no appreciable impact on environment

appreciable impact and appropriate measures required significant impact; major environmental control required major impact; project site to be reviewed not suitable; alternate site to be considered.

\section{Nomenclature Used}

\begin{tabular}{llll} 
W: & Weight & A: & \multicolumn{2}{c}{ plant activity } \\
B: & Solid Waste & C: & liquid effluent \\
D: & gas emissions & E: & Community Development \\
F: & Transport & G: & Institution \\
H: & Plantation & NE: & Net Effect \\
S: & Scores & EP: & Environment Parameter
\end{tabular}

Source: Larry, W. Canter; Environment Impact Assessment; "Simple Methods for Impact IdentificationMatrices, Networks and Checklists"; Chapter 3, (8)

The impact Matrix of the project is shown in the table below

\begin{tabular}{|l|l|l|l|l|l|l|l|l|l|l|l|}
\hline EP & W & A & B & C & D & E & F & G & H & NE & S \\
\hline Land & $\mathbf{1 0 0}$ & -3 & -6 & -6 & 0 & 2 & 1 & 2 & 4 & -6 & -600 \\
\hline $\begin{array}{l}\text { Biotic } \\
\text { Envt }\end{array}$ & $\mathbf{1 0 0}$ & -3 & -3 & -3 & -4 & 0 & 0 & 0 & 4 & -9 & -900 \\
\hline $\begin{array}{l}\text { Air } \\
\text { Quality }\end{array}$ & $\mathbf{1 5 0}$ & -3 & 0 & 0 & -6 & -1 & -2 & -1 & 2 & -11 & - \\
\hline $\begin{array}{l}\text { Ground } \\
\text { Water }\end{array}$ & $\mathbf{1 5 0}$ & -3 & -6 & -6 & 0 & -1 & 0 & 0 & 2 & -10 & - \\
\hline Health & $\mathbf{1 0 0}$ & -2 & -3 & -3 & -6 & -1 & -1 & 0 & 2 & -14 & - \\
\hline
\end{tabular}




\section{Net total $=-\mathbf{- 7 4 0 0}$}

\begin{tabular}{|l|l|l|l|l|l|l|l|l|l|l|l|}
\hline & & & & & & & & & & & 1400 \\
\hline Noise & $\mathbf{1 0 0}$ & -4 & 0 & 0 & 0 & 0 & -1 & -1 & 0 & -6 & -600 \\
\hline Employ & $\mathbf{1 0 0}$ & 4 & 1 & 1 & 1 & 4 & 2 & 2 & 0 & 15 & 1500 \\
\hline Literacy & $\mathbf{5 0}$ & 1 & 0 & 0 & 0 & 3 & 1 & 4 & 0 & 9 & 450 \\
\hline Safety & $\mathbf{1 5 0}$ & -2 & -5 & -4 & -6 & -1 & -1 & 0 & 1 & -18 & - \\
\hline $\begin{array}{l}\text { Aesth } \\
\text { etics }\end{array}$ & $\mathbf{5 0}$ & -1 & -2 & -2 & -2 & 1 & -1 & 1 & 4 & 0 & 0 \\
\hline
\end{tabular}

The project, without the mitigative measures scores -7400 points. This indicates that there is a significant impact and major environmental control measures are required.

\section{Mitigation Measures}

Different mitigation measures to be adopted for different environmental parameters are as follows:

\begin{tabular}{|c|c|c|c|}
\hline S.No & Parameter & \multicolumn{2}{|c|}{ Control through EMP } \\
\hline \multirow[b]{2}{*}{1.} & \multirow[b]{2}{*}{ Groundwater } & Construction Phase & - $\quad$ Septic tank \\
\hline & & Operational Phase & $\begin{array}{ll}\text { - } & \text { Rain water harvesting } \\
\text { - } & \text { Storm water storage } \\
\text { - } & \text { Sewage sludge to be } \\
& \text { used as manure }\end{array}$ \\
\hline \multirow[t]{2}{*}{2.} & \multirow[t]{2}{*}{ Air quality } & Construction Phase & $\begin{array}{ll}- & \text { On site dust control } \\
\text { measures } \\
\text { - } \\
\text { Emission control } \\
\text { particle filters on } \\
\text { construction equipments }\end{array}$ \\
\hline & & Operational Phase & $\begin{array}{ll}- & \text { Plantation of specific } \\
\text { species will reduce SPM } \\
\text { concentration. }\end{array}$ \\
\hline \multirow[t]{2}{*}{3.} & \multirow{2}{*}{$\begin{array}{l}\text { Noise } \\
\text { environment }\end{array}$} & Construction Phase & $\begin{array}{ll}- & \text { Equipments fitted with } \\
& \text { silencers } \\
- & \text { Providing noise shields } \\
& \text { near heavy construction } \\
\end{array}$ \\
\hline & & Operational Phase & $\begin{array}{ll} & \text { On site plantation } \\
\text { - } & \text { Acoustic enclosures to } \\
& \text { be provided }\end{array}$ \\
\hline \multirow[t]{2}{*}{4.} & \multirow[t]{2}{*}{$\begin{array}{l}\text { Land } \\
\text { environment }\end{array}$} & Construction Phase & $\begin{array}{l}\text { - Construction debris will } \\
\text { be collected and used on } \\
\text { site as per construction } \\
\text { - Waste management plan }\end{array}$ \\
\hline & & Operational Phase & $\begin{array}{l}\text { - On site waste collection, } \\
\text { segregation and } \\
\text { treatment. }\end{array}$ \\
\hline 5. & $\begin{array}{l}\text { Biological } \\
\text { environment }\end{array}$ & Operational Phase & $\begin{array}{l}\text { - Suitable plantation will } \\
\text { be done }\end{array}$ \\
\hline 6. & $\begin{array}{l}\text { Socio- } \\
\text { economic } \\
\text { environment }\end{array}$ & Operational Phase & $\begin{array}{ll}\text { Enhanced commercial \& } \\
\text { economic activities }\end{array}$ \\
\hline \multirow[b]{2}{*}{7.} & \multirow[b]{2}{*}{$\begin{array}{l}\text { Traffic } \\
\text { pattern }\end{array}$} & Construction Phase & $\begin{array}{ll}- & \text { Heavy vehicular } \\
& \text { movement only at site }\end{array}$ \\
\hline & & Operational Phase & $\begin{array}{l}\text { NH21 has adequate } \\
\text { capacity to } \\
\text { accommodate additional } \\
\text { traffic from the project }\end{array}$ \\
\hline
\end{tabular}

Based on above mitigation measures an activity matrix has been developed .The criteria adopted is same as per in formulation of Matrix above. 


\begin{tabular}{|c|c|c|c|c|c|c|c|c|c|c|c|}
\hline$\overline{\text { EP }}$ & $\overline{\mathbf{W}}$ & $\overline{\mathbf{A}}$ & B & $\bar{C}$ & D & $\mathbf{E}$ & $\overline{\mathbf{F}}$ & $\overline{\mathbf{G}}$ & $\mathbf{H}$ & NE & $\overline{\mathbf{S}}$ \\
\hline Land & 100 & -3 & 0 & 0 & 0 & 1 & 1 & 2 & 4 & 5 & 500 \\
\hline $\begin{array}{l}\text { Biotic } \\
\text { Envt }\end{array}$ & 100 & -1 & 0 & $\mathbf{0}$ & -2 & $\mathbf{0}$ & $\mathbf{0}$ & $\mathbf{0}$ & 4 & 1 & 100 \\
\hline $\begin{array}{l}\text { Air } \\
\text { Quality }\end{array}$ & 150 & -2 & $\mathbf{0}$ & $\mathbf{0}$ & -2 & -1 & -1 & -1 & 2 & -5 & -750 \\
\hline $\begin{array}{l}\text { Ground } \\
\text { Water }\end{array}$ & 150 & -2 & 0 & -2 & 0 & -1 & $\mathbf{0}$ & 0 & 2 & -3 & -450 \\
\hline Health & 100 & -1 & -1 & -1 & -2 & -1 & -1 & $\mathbf{0}$ & 2 & -5 & -500 \\
\hline Noise & 100 & -2 & 0 & $\mathbf{0}$ & $\mathbf{0}$ & $\mathbf{0}$ & $\mathbf{0}$ & -1 & $\mathbf{0}$ & -3 & -300 \\
\hline Employ & 100 & 4 & 1 & 1 & 1 & 3 & 2 & 2 & $\mathbf{0}$ & 14 & 1400 \\
\hline Literacy & 50 & 1 & $\mathbf{0}$ & $\mathbf{0}$ & $\mathbf{0}$ & 3 & 1 & 4 & $\mathbf{0}$ & 9 & 450 \\
\hline Safety & 150 & -1 & -1 & -2 & -2 & -1 & -1 & $\mathbf{0}$ & 1 & -7 & $\begin{array}{l}- \\
1050\end{array}$ \\
\hline $\begin{array}{l}\text { Aesth } \\
\text { etics }\end{array}$ & 50 & 1 & -1 & -1 & -1 & 1 & 1 & 1 & 4 & 5 & 250 \\
\hline
\end{tabular}

Net total $=\mathbf{- 3 5 0}$

The project scored -350 points with mitigation measure. This indicates that there would not be appreciable impact on the environment with appropriate environmental control measures.

\section{Environment Impact Statement:}

Compromises have to be made so that an adversity on one hand is offset by benefits on other. The Ministry of environment and Forests, through Central Pollution Control Board has quantified degree of compromise, by fixing permissible limits of discharge of common pollutants. A company, willing to set up a project has only to ensure that these guidelines are met, in addition to selecting an approved site.

The development project of a Multiplex would not have any significant adverse impact on the environment. Adequate measures are proposed to minimise the effect of various pollutants.

The activity impact Matrix for the upcoming mall cum multiplex, has been evaluated for two cases: one without the mitigation measures and other with the mitigation measures. The development project scored -7400 points without the implementation of mitigation measures. This indicates that there would be significant impact on the environment and major environmental control measures are required.

With the implementation of environmental mitigation measures the development project scored 350points. This indicates that there would not be appreciable impact on the environment with appropriate and suitable control measures.

Impact on Air Environment will not be significant since installing appropriate devices and adopting techniques to control pollution.

Waste water will be released after treatment, through an efficient system as sewage treatment plant, will have negligible concentration of pollutants.

For handling solid waste, an elaborate and efficient plan has been proposed to ensure that it is not released in the environment.

Impact during construction phase would be confined to the site premises only. The project scored -350 points, after it implements proposed pollution control measures. Thus, the project can be classified, as having insignificant \& negligible impact on environment.

\section{Acknowledgement}

I would like to thank PEC University of technology, for providing all the facilities and encouragement for carrying out the work.

\section{References}

[1.] Alshuwaikat Habib. M (2005), "Strategic Environmental Assessment can help solve Environmental Impact Assessment failures in Developing Countries", department of city and regional planning, king Fahad University of petroleum and minerals, Dhahran, Saudi Arabia.

[2.] Anjaneyulu Y, "Environment Impact Assessment Methodologies", B.S Publications.

[3.] Aruna Murthy, Himansu Sekhar Patra (2005), "Environmental Impact Assessment process in India and its drawbacks", Bhubaneshwar.

[4.] Bhattacharjee P.K. "An overview of EIA for River Valley Project", proceedings of XV1 National Conference of Environmental Engineers, Pg1-28 to 1-36.

[5.] Canter W Larry (1996), "Environmental Impact Assessment”, Mc Graw Hill.

[6.] Canter W Larry, Fairchild D M (1993), "Post- EIS Environmental Monitoring Impact Assessment Bulletin”.

[7.] Chen Z., Li H., Hong J. (2004). "An integrative methodology for environmental management in construction". Automation in Construction 13:621-628. 
[8.] Christopher Wood (2003), conference on "Environment Impact Assessment in Developing countries", School of planning and landscape, University of Manchester, Manchester M13 9PL.

[9.] Deshpande V.A.\& Goyal, S.K. (2008) Environment impact evaluation in EIA studies: A new approach , IJEP 18 (11): 824-829.

[10.] Eddy \& Metcalf, INC, revised by George Tchobanologous, "Waste water engineering treatment, Disposal, Reuse", Tata Mcgraw Hill, Second Edition

[11.] EIA implementation and follow up: a case study of Koga irrigation and watershed management project-Ethiopia

[12.] Environmental Impact Assessment Review (2008) Volume: 28, Issue: 7, Publisher: Elsevier, Pages: 469-482.

[13.] Environment Impact Notification 2006; Gazette of India, 14th September, 2006

[14.] G. Raghuram, Samantha Bastian, Satyam Shivam Sundaram (2009)," Mega projects in India Environmental and Land Acquisition Issues in the Road Sector", Indian Institute of Management, Ahmadabad.

[15.] Garg, Santosh kumar, "Water supply engineering- Environmental Engineering, Volume 1 \& 2", Khanna Publishers.

[16.] Gilpin, A (1995), "Environmental Impact Assessment (EIA)": Cutting Edge for the twenty first century, Cambridge University Press, Cambridge, U.K.

[17.] Humood A. Naser, (2012), "Evaluation of the Environmental Impact Assessment System in Bahrain", Journal of Environmental Protection, 2012, 3, 233-239.

[18.] Jan Joost Kessler, "integrated assessment and planning for Sustainable development".

[19.] Lam P.T.I., Chan E.H.W., Chau C.K., Poon C.S., Chun K.P. (2011). "Environmental management system vs green specifications: How do they complement each other in the construction industry?" Journal of Environmental Management 92:788-795.

[20.] Levin H. (1997). "Systematic Evaluation and Assessment of Building Environmental Performance (SEABEP)", paper for presentation to "Buildings and Environment" :Paris, 9-12 June,1997.

[21.] Marsh, Willium, M., (1972), "Environmental Impact Analysis", New York.

[22.] Mr Jorma Jantunen (2005), "Case study of an EIA in Finland, development of Highway 1 (E18)”, Uusimaa Regional Environment Centre.

[23.] Peavey Howard S, Rowe Donald, Tchobanogolous George (1985), "Environmental Engineering", Mcgraw Hills International Edition.

[24.] Samaneh Zolfagharian, Mehdi Nourbakhsh, Javier Irizarry, Aziruddin Ressang, Masoud Gheisari (2012), "Environmental Impact Assessment on Construction site", Construction Research Congress 2012 @ ASCE 2012

[25.] Shen L.-Y., Lu W.-S., Yao H., Wu D.-H. (2005). "A computer-based scoring method for measuring the environmental performance of construction activities", Automation in Construction 14:297-309.

[26.] "The integration of Environmental Impact Assessment and Environmental Management Systems", L. Palframan, School of Life Sciences, University of Hertfordshire, Hatfield AL10 9AB UK.

[27.] Tracy Glynn (2004), "Environmental Impact Assessment: a guide for reviewers", pg 3, 5-13.

[28.] Tse Y., Raymond V. (2001). "The implementation of EMS in construction firms: case study in Hong Kong". Journal of Environmental Assessment Policy and Management 3:94, 177.

[29.] Vitalis Justin Moduying(2001), "Environmental Impact Assessment (EIA) System in Sabah", 6th SITE Research Seminar, 13-14 September 2001

[30.] W.B. Abebe, W.J.A.M. Douven, M.McCartney, J. Leentvaar(2007), "EIA implementation and follow up: a case study of Koga irrigation and watershed management project- Ethiopia”, pg 1-3.

[31.] 2nd International Conference on Challenges in Environmental. Procedia Environmental Sciences Volume 11, (pp. 1499-1507). 